\title{
THE MOTIVATION TOWARD TECHNICAL EDUCATION OF STUDENTS IN PRE-PRIMARY AND PRIMERY EDUCATION PROGRAMS
}

Martin KURUC*, Univerzita Komenského v Bratislave, Slovenská republika Mária KOŽUCHOVÁ, Univerzita Komenského v Bratislave, Slovenská republika

Přijato: 26. 12. 2019 / Akceptováno: 20. 1. 2020

Typ článku: výskumný článok

DOI: $10.5507 /$ jtie.2020.002

Abstract In our paper, we present the results and interpretations of our research, which aimed to map the current settings of self-regulation and motivation of pre-primary and primary school university students. We focused on three areas. On self-regulation and motivation for science, mathematical disciplines, and technology education. The research is based on the methodological approach of The Theory of Self-Determination. The most important finding is the positive setting of student motivation to technology education. The Identified regulatory style to technical education prevailed among students of pre-primary and primary education programs.

Key words: self-regulation, motivation, self-determination, technical education.

\section{MOTIVÁCIA K TECHNICKÉMU VZDELÁVANIU U ŠTUDENTOV PROGRAMOV PRED-PRIMÁRNE A PRIMÁRNE VZDELÁVANIE}

Abstrakt: V príspevku predstavujeme výsledky a interpretácie z nášho výskumu, ktorého ciel'om bolo zmapovat' aktuálne nastavenie sebaregulácie a motivácie u študentov predprimárneho a primárneho vzdelávania. Sústredili sme sa na tri oblasti. Na oblast' sebaregulácie a motivácie k prírodovedným predmetom, matematickým disciplínam a technike. Vychádzame z metodologického prístupu ukotveného $v$ teórii sebaurčenia. Za najvýznamnejšie zistenie považujeme pozitívne nastavenie motivácie študentov $k$ technike. Vo vzt’ahu $k$ technike prevládali u študentov tzv. identifikované motívy.

Klúčové slová: sebaregulácia, motivácia, sebaurčenie, technické vzdelávanie

*Autor pro korespondenci: kuruc@fedu.uniba.sk 


\section{1 Úvod}

Problematika sebaregulácie učenia sa je v zahraničí rozšírenou témou. U nás sa tejto problematike nevenuje vel'ká pozornost'. Sme toho názoru, že sebaregulácia učenia sa študentov vel'mi úzko súvisí s ich školským úspechom, rovnako aj s učením sa žiakov, ktorých budú vzdelávat'. Ak ich budú chciet' pripravit' pre život, nebudú stačit' len vedomosti. Je potrebné osvojit' si novú kultúru učenia sa, ktorá sa bude vyznačovat' väčšou individualizáciou pri konštruovaní vedomosti, kooperatívnost'ou, samostatnostou a zodpovednost'ou učiacého sa subjektu (Maňák, 2006).

Už v roku 1997 bola v SR zaradená do Národného programu výchovy a vzdelávania kompetencia „učit’ sa učit““ (NPRVaV, 1998). UNESCO uvádza, že základným pilierom tejto kompetencie je učit' sa poznávat', učit' sa konat' a učit' sa žit' (UNESCO, 1997). Maňák (2009) upozorňuje na potrebu selekcie informácií, ale aj na potrebu rozvoja d’alších vlastnosti osobnosti v súvislosti s nepreberným množstvom informácií. Súčasná spoločnost' sa celosvetovo vo svojom rozvoji dostala na križovatku. Speje k bodu obratu, čo v edukácii znamená väčší dôraz na výber informácií, aktívnu konštrukciu poznania, na rozvoj tvorivosti a myslenia, na syntézu a zovšeobecȟovanie ako na transfer a pamätanie si informácii.

Európa stojí pred d’alším problémom, čelí nedostatku kvalifikovaných pracovných síl v odboroch, ktoré sú zamerané na matematiku, ale aj prírodovedné a technické predmety. Aj ked' celkový počet absolventov so stredoškolským a vysokoškolským vzdelaním vzrástol, záujem o spomínané odbory klesá. Je to hrozba pre súčasnú ekonomiku, preto zvyšovanie počtu absolventov vodboroch s matematickým, prírodovedným a technickým zameraním je jednou z hlavných priorít všetkých európskych krajín. Opatrenia by mali smerovat' až k elementárnemu vzdelávaniu. V prvom rade by malo íst' o zvýšenie motivácie žiakov učit' sa spomínané predmety. Dôvodov, prečo sú žiaci ZŠ neúspešní v týchto predmetoch a nemajú záujem ich študovat' vo vlastnej profesijnej kariére je pomerne vel'a. Jedným z nich, hlavne na primárnom stupni ZŠ je, že ani samotní učitelia nie sú motivovaní. Ukázalo sa, že učitelia primárneho stupňa počas štúdia mali najväčšie problémy práve s matematikou a medzi neobl'úbené predmety patrili aj niektoré prírodovedné, či technické disciplíny. $Z$ toho dôvodu sme sa začali zaoberat' otázkou, ako u študentov zvýšit' záujem o matematické, prírodovedné, či technické disciplíny. Je to naša úloha na najbližšie tri roky, v rámci projektu VEGA č. 1/0443/18 - Analýza sebaregulačných štýlov učenia sa študentov odboru predškolská a elementárna pedagogika. Kladieme si za ciel' priblížit' študentom model sebaregulácie učenia sa. Poukázat’ na to, akú významnú rolu zohrávajú nonkognitívne faktory v procese učenia a prečo je dôležité prevziat' svoje učenie do vlastných rúk.

\section{2 Činitele ovplyvňujúce sebareguláciu učenia}

V prvom rade je potrebné objasnit' samotný pojem sebaregulácia učenia sa. Podl'a Pintricha (2005) ide o taký spôsob učenia, pri ktorom sa samotný žiak stáva aktérom svojho vlastného procesu učenia po stránke činnostnej, motivačnej či metakognitívnej. Snaží sa pritom dosiahnut' určité ciele, iniciuje a riadi svoje vlastné poznávacie úsilie, používa špecifické stratégie učenia sa s ohl'adom na kontext, v ktorom sa učenie odohráva. Prepája tak akcent osobnosti a individuality so sociálnou dimenziou učenia.

Podl'a Zimmermana (2001) sebaregulácia učenia sa človeku nie je daná, ani osvojitel'ná učebná zručnost', ale skôr ide o proces riadenia seba samého, pri ktorom učiaci sa transformuje svoje duševné schopnosti do zručností potrebných pre učenie. 
Učenie $\mathrm{v}$ tomto poňatí nie je niečo, čo smeruje od učitel’a $\mathrm{k}$ študentom, ale niečo, čo prichádza od študentov samotných. Študent pri nich reguluje jednak kognitívnu (poznávaciu) dimenziu vzdelávania, ale aj nonkognitívnu dimenziu učenia sa (motiváciu, vôl'u, emócie....).

Garcia (1995) sebareguláciu učenia sa chápe v zmysle prepojenia zručností a vôle (skills and will). Zručnosti (skills) sa vzt’ahujú $\mathrm{k}$ vol'be potrebnej stratégie, ale ich účinnost' závisí taktiež od osobného očakávania, presvedčenia, teda je závislá od hodnôt a postojov človeka, ktoré ovplyvňujú ochotu - vôlu (will) človeka konat'. Proces poznávania si možno len t’ažko predstavit' bez vôle - exekutívnych procesov. Ide o schopnosti ako sústredenie, presúvanie pozornosti, plánovanie, riešenie problémov, rozhodovanie atd'. Exekutívne procesy sú považované za metaprocesy, ktoré koordinujú ostatné kognitívne procesy. (Breisby a Gellatly, 2005)

Hrbačková (2010) sebareguláciu učenia sa definuje ako proces, počas ktorého si subjekt uvedomuje, čo a ako aj prečo robí. Proces, v ktorom sebareflektuje vlastné učebné aktivity i ich efekty a ktorého výsledkom je individuálny "projekt" subjektu (žiaka), ako má d’alej v učení (v širšom zmysle slova vo vzdelávaní) pokračovat', na čo sa zamerat', čo zlepšit', zdokonalit', čo posilnit' v danom kontexte procesu učenia sa.

Z definícií sebaregulácie učenia sa vyplýva, že proces učenia ovplyvňuje celý rad činitel'ov. Môžeme tu zaradit' kognitívne činitele, napríklad inteligenciu jedinca, spôsob spracovávania informácií a tiež kreativitu. Medzi afektívne činitele patria emócie, pocity, hodnoty, postoje a návyky jedinca. Medzi biologické činitele zasa zrenie, vek, pohlavie ale aj zdravotný stav. A významnú úlohu zohrávajú aj sociokultúrne činitele. Sociokultúrna odlišnost' znamená, že jedinec sa od detstva stretáva s inými skúsenost'ami, než žiaci väčšinovej spoločnosti. Žije v prostredí pôsobenia iných sociokultúrnych vplyvov, dochádza k iným podmienkam socializácie.

Afektívne činitele ako sú napríklad emócie výrazne ovplyvňujú proces učenia, či už sú pozitívne (príjemné ako radost', št’astie) alebo negatívne (nepríjemné ako strach, smútok a hnev). Nepríjemné emócie zužujú pozornost' a naopak príjemné emócie pozornost' rozširujú, zvyšujú tvorivost' a umožňujú jednoduchšie chápanie súvislostí. Afektívne činitele majú vplyv aj na zapamätanie a neskoršie vybavenie poznatkov, ovplyvňujú rozsah získavaných informácií a tiež motiváciu pri dosahovaní ciel’ov (Mareš, 2013).

V celej učebnej stratégii je dôležité stanovenie ciel’a. Každý jedinec si ho prevedie do štruktúry vlastných možností. Tým začína regulovat' proces vlastného učenia sa. Aj vôl'a zohráva dôležitú úlohu $\mathrm{v}$ tom, či jedinec $\mathrm{v}$ učení vytrvá a nevzdá sa pri prvých t’ažkostiach.

Vôla zotrvat' pri učení závisí aj od učebnej stratégie. Jedinec stratégiu volí podla toho, ako sa mu osvedčila pri riešení podobnej úlohy $\mathrm{v}$ minulosti a podla toho, akú úspešnost' tejto stratégii pripisuje. Klúčcvú úlohu v naštartovaní procesu sebaregulácie učenia sa zohráva motivácia, ktorou proces sebaregulácie v podstate začína. Motivácia je faktor, ktorý zvyšuje alebo naopak znižuje intenzitu aktivácie jedinca. Samotní učitelia môžu u svojich študentov podporit’ rozvoj sebaregulácie učenia tým, že u nich navodia pocit významnosti úlohy, že daná úloha má zmysel. Dnešný učitel' stojí pred vel'kou výzvou: ako riadit' proces edukácie, aby bol zmyselný a spojený s rozvojom osobnosti žiaka? Odpoved’ou na túto výzvu, môže byt' autonómiu podporujúce učenie postavené na Teórii sebaurčenia (Self-Determination Theory, d’alej SDT). Ústrednou 
témou nášho prístupu je motivácia, ktorá sa výrazne podpisuje pod výsledky učenia sa a je úzko prepojená so sebareguláciou, preto sa jej budeme v nasledujúcej časti príspevku venovat' podrobnejšie.

\section{Motivácia ako významný činitel' sebaregulácie učenia}

Motivácia je jednou z významných zložiek psychickej regulácie činnosti, ktorá napomáha $\mathrm{k}$ fungovaniu učenia. Aktivizuje kognitívne systémy na dosahovanie určitých ciel’ov, u jedinca podporuje také správanie, ktoré si udržuje dynamický rast osobnosti a vnútornú rovnováhu (Nakonečný, 1996).

Pojem motivácia sa vzt’ahuje $\mathrm{k}$ faktorom, ktoré zvyšujú alebo naopak znižujú intenzitu aktivácie jedinca (Kusák \& Dařílek, 2002). Motiváciu k učeniu vnímame ako súhrn činitel'ov, ktoré podnecujú, energizujú a riadia priebeh učenia sa študenta (Hrabal, Man, \& Pavelková, 1989). Zahŕňa v sebe energiu, smerovanie i vytrvalost', t.j. rôzne aspekty aktivity (Hrbáčková, 2010). Ak sa študent stretne s novou úlohou, pristupuje k nej podl'a toho, akú dôležitost' tejto úlohe prisudzuje, čo vo svojom dôsledku ovplyvní jeho motivačnú orientáciu. Ak študent pri plnení úlohy sám seba vníma ako nekompetentného, pristupuje $\mathrm{k}$ jej vyriešeniu inak ako iný študent, ktorý sa za kompetentného považuje. Motivácia hrá klúčovú úlohu $\mathrm{v}$ naštartovaní procesu sebaregulácie učenia a do istej miery môže kompenzovat' aj nedostatok schopností.

Na motiváciu $\mathrm{k}$ učeniu pôsobí celý rad faktorov, ako sú napríklad novost' situácie, aktivita jedinca, sociálne faktory, stanovený ciel', záujem jedinca o učivo, tendencie dokončit rozrobenú činnost', odmeny a tresty, dosiahnutý úspech, či neúspech (Klusák \& Dařílek, 2002). Podl'a Hrbáčkovej (2011) medzi faktory ovplyvňujúce motiváciu učenia sa patrí: osobná zdatnost' jedinca - presvedčenie o kompetentnosti, orientácia na ciel', presvedčenie o zmysluplnosti učenia, atribučné presvedčenie.

Osobná zdatnost' jedinca - predstavuje to, ako sa študenti (žiaci) angažujú v určitej oblasti učenia sa. Jeho presvedčenie o vlastnej kompetentnosti (Boekaerts, 2005). Vyššia úroveň osobnej zdatnosti zvyšuje výkon človeka a jeho duševnú pohodu. Jedinec s vyššou úrovňou osobnej zdatnosti vníma t'ažké úlohy ako výzvu, neúspech prisudzuje nedostatočnému úsiliu, má aj väčšie túžby, kladie na seba väčšie nároky a chce plnit' t’ažké ciele, má aj vyššiu mieru vnútornej motivácie. Naopak jedinec, ktorý má nízku úroveň osobnej zdatnosti, si stanovuje menšie ciele, vyhýba sa prekážkam, a ked’ už na nejaké prekážky narazí, tak sa l’ahko vzdáva. Takýto jedinec svoj neúspech prisudzuje neovplyvnitel’ným príčinám. Pre jedinca je dôležité vnímanie pričin úspechu a neúspechu, čím môže posilňovat' svoju osobnú zdatnost' úspechom, alebo oslabovat' neúspechom. Kauzálna atribúcia má vplyv na úroveň sebavedomia jedinca a na d’alší vývoj motivácie k výkonu.

Orientácia na ciel' - zásadným spôsobom ovplyvňuje sebareguláciu a proces učenia sa jedinca. Jedinec môže byt' zameraný na proces učenia, učí sa preto, aby zvládol novú zručnost' a ciel'om je zvládnutie daného učiva. Jedinec sa môže sústredit' aj na výsledok svojho učenia, je teda zameraný na demonštráciu novej zručnosti. Správanie sa orientované na ciel' je napríklad študentovo želanie úspešne ukončit vysokoškolské štúdium (Nolen-Hoeksema, 2012).

Presvedčenie o zmysluplnosti učenia - je vnímaná hodnota úlohy, to či úloha, resp. učivo jedinec vníma ako zmysluplné a je nejakým spôsobom pre neho samotného 
prínosné. Jedinec má väčšiu motiváciu $\mathrm{k}$ učeniu, ked’ sú učebné ciele $\mathrm{v}$ súlade $\mathrm{s}$ jeho potrebami a jeho očakávaním.

Atribučné presvedčenie - to čomu jedinci pripisujú pričinu vlastného úspechu alebo neúspechu. Kauzálne atribúcia má vplyv na úroveň sebavedomia jedinca a na d’alší vývoj motivácie $\mathrm{k}$ výkonu. Jedinci môžu svoj neúspech (úspech) pripisovat', bud’ vnútorným schopnostiam alebo vonkajším okolnostiam. Hovoríme tak o internej atribúcii, kedy sú príčiny pripisované schopností jednotlivca a o externej atribúcii, kedy jedinec príčiny pripisuje okoliu, osobám, situácií, náhode pod. (Nakonečný, 2016).

V odborných diskusiách prevláda aj dnes bipolárne videnie vonkajšej a vnútornej motivácie. Vnútorná motivácia je vnímaná ako tá dobrá a vonkajšia ako tá zlá. Ide skôr o historické chápanie týchto pojmov. Teória sebaurčenia autorov Deciho a Ryana (Deci a Ryan, 2004) ponúka iný pohl'ad, ktorý je výsledkom dlhodobého skúmania a odborných diskusií. Vonkajšia a vnútorná motivácia sa navzájom dopĺn̆ajú, pričom tak, ako je pre človeka vnútorne prirodzené aktualizovat' svoj vlastný potenciál, tak aj vonkajšia motivácia je prirodzenou súčast'ou nášho prostredia a jedinec ju môže vnímat' ako niečo prirodzené. Nie je bud' vnútorná alebo vonkajšia motivácia, ale ide o neustálu interakciu medzi vnútornými pohnútkami (napr. ašpiráciami) jedinca a jeho možnost’ami (napr. očakávaniami) sociálneho prostredia.

Výskumy, ktoré realizovala Boekaerts (2005) dokazujú, že proces sebaregulácie učenia je v priamom spojení s vnútornou motiváciou. V jej modeli hrá významnú úlohu fakt, že študenti, ktorí disponujú zručnost’ami sebaregulácie v určitej oblasti učenia sa, v inej oblasti môžu byt' závislí na vonkajšej kontrole a vykazovat' nízku úroveň sebaregulácie. Boekaertsovej (2005) model sa vzt’ahuje len na istú špecifickú oblast' učenia. Žiak s vysokou úrovňou regulácie v humanitných vedách nemusí disponovat' zručnost'ami sebaregulácie $\mathrm{v}$ matematike. Je ale potrebné podotknút', že motivačná orientácia sa môže v priebehu času menit'. O aktivitu, ktorú študent vykonával pred časom z vlastnej iniciatívy, v súčasnosti už nemusí javit' záujem. Navyše je vel'mi individuálna. To, čo je pre jedného študenta vel'mi zaujímavé, pre iného študenta rovnakého veku či pohlavia nemusí byt' zaujímavé.

Odmeny a tresty hrajú významnú úlohu v motivačnej orientácii študenta. Úroveň vnútornej motivácie sa môže rozvíjat', zvyšovat', ale môže tiež slabnút. Ak študent vykonáva určitú aktivitu z vnútorných pohnútok, pre vlastné potešenie, môže sa stat', že stratí o túto činnost' záujem v prípade, že mu je opakovane ponúkaná vonkajšej odmena. Riziko odmien býva popisované predovšetkým v súvislosti s chápaním vonkajšieho spevnenia. Ak študent chápe odmenu ako kontrolný mechanizmus aktivity, potom sa táto aktivita a jej výsledok stáva vo svojom dôsledku niečím, čo stojí mimo študenta samotného, čo nemôže ovplyvnit', a teda ani riadit'. Ak je odmena chápaná ako informácia (odmena je niečo, čo poskytuje študentovi spätnú väzbu toho, ako si v určitej aktivite viedol), potom ju študent vníma ako impulz, aby mohol samostatne rozhodnút', ako aktivitu riadit', cítit' sa kompetentní.

Vo svojom výskume predpokladáme, že existuje vel’a študentov, ktorí sú motivovaní zvonku a majú nízku úroveň vnútornej motivácie. Sme toho názoru, že vnútorná motivácia môže byt' ovplyvnená (rozvíjaná) postupne tým, že sa učitel' zameria na motivačné presvedčenie študentov (identifikuje ho) a ponúkne aktivity, ktoré sú v súlade $\mathrm{s}$ ich potrebami. Vnútorná motivácia môže byt' rozvíjaná aktivitami, ktoré sú pre študentov výzvou (nie sú študentom vnímané ako príliš jednoduché, ani ako príliš tažké). 
Ďalej môže íst' o aktivity, ktoré vzbudzujú u študentov zvedavost', alebo poskytujú študentom možnost' slobodnej vol'by, či aktivity, ktoré sú z pohl'adu študenta zmysluplné.

\section{Východisková teória výskumu}

V našom výskume sa opierame o teóriu sebaurčenia (Self-determination Theory, d’alej len SDT), ktorú konštituovali Edward L. Deci v úzkej spolupráci s Richardom M. Ryanom z Rochester University, US. $(1975,1980)$ Pre zber dát sme využili modifikovanú formu dotazníka SRQ-Academic konštruovanú v zmysle princípov tejto teórie.

Teória sebaurčenia sa snaží vysvetl'ovat' charakter motivácie z hl'adiska sociálnych kontextov a následne definovat' charakter regulácie človeka, t.j. aký sebaregulačný štýl použiva v rôznych sociálnych kontextoch.

Samotná teória je vybudovaná na troch hlavných subteóriách a jednej relatívne samostatnej teórii. Ide o tieto subteórie:

Teória kognitívnej evaluácie (Cognitive Evaluation Theory), ktorej hlavným ciel'om bolo popísat' účinky sociálnych kontextov na vnútornú motiváciu. Vymedzuje tzv. kontextuálne elementy, ktoré na jednej strane podporujú vnútornú motiváciu - miera autonómie, na druhej strane oslabujú vnútornú motiváciu - miera kontroly a napokon tie, ktoré prítomnost' vnútornej motivácie úplne vylučujú - stav amotivácie (Ryan, 2012). Tato subteória teda definuje tie základné konštrukty sociálnych kontextov, ktoré u človeka vnútornú motiváciu ovplyvňujú pozitívne (zosilňujú ju) alebo negatívne (oslabujú ju).

Teória organizmickej integrácie (Organizmic Integration Theory), ktorá bola konštituovaná ako druhá, mala za ciel' formulovat' vysvetlenia pre vývin a dynamiku vonkajšej motivácie. Sústred’uje sa na proces internalizácie a integrácie hodnôt a regulácie správania. Internalizáciu vníma ako prirodzený proces, v ktorom l’udia aktívne pracujú na transformácii externých regulácií do sebaregulácie, t.j. do stále viac integrovaného systému osobnosti. Táto subteória priniesla nový integrujúci pohl'ad na problematiku vonkajšej a vnútornej motivácie, ktorý sme opísali vyššie.

Teória kauzálnych orientácií (Causality Orientations Theory) bola zostavená ako tretia. Jej ciel'om bolo zoskupenie individuálnych rozdielov v l'udských tendenciách orientovat' svoje prežívanie a správanie vo vzt’ahu k sociálnemu prostrediu. Ryan a Deci (2004) vymedzujú tri relatívne stabilné tendencie: orientáciu na autonómiu, kedy ide o tendenciu smerujúcu k podpore vnútornej motivácii a sebaregulácii. Orientáciu na kontrolu - tendenciu, ktorá vychádza z vonkajšej motivácie, v závislosti na miere internalizácie (až integrácie). Napokon vymedzujú impersonálnu (neosobnú) tendenciu, pre ktorú je charakteristická amotivácia, výrazná až úplná závislost' na sociálnych vplyvoch z prostredia. Na základe záverov tejto teórie je možné predikovat' prežívanie a správanie z tzv. relatívne trvalých orientácií človeka.

Nosnou je ale Teória základných potrieb (Basic Needs Theory), v nej sú vymedzené tri základné psychologické potreby a tvorí základ, z ktorého vychádzajú aj vyššie opísané subteórie. Táto teória vymedzuje tieto tri potreby:

1. Potrebu kompetencie, ktorá predstavuje prirodzenú potrebu človeka na vyhl'adávanie výzvy, ktoré sú optimálne pre jeho vlastné, aktuálne kapacity. Ide o vedomé vnímanie vlastnej dôvery a efektivity vo vykonávanej aktivite. Túto potrebu 
môžeme vnímat' ako prirodzenú tendenciu človeka vyhl'adávat' aktivity, pri ktorých prežíva skúsenost' vlastnej schopnosti, tzn., že máme potrebu byt' schopní.

2. Potreba vztahovosti predstavuje prežívanie pocitu prepojenia z ostatnými, potrebu byt' súčast'ou vzt’ahov v skupine, komunite. Preživanie pocitu, že sme s druhými $\mathrm{v}$ bezpečnom spojení. Najsilnejšia je $\mathrm{v}$ prvých troch rokoch života ako súčast' potreby pripútania kvzt'ahovej osobe (attachement). Ide o inherentnú potrebu človeka byt' súčastou blízkych a láskavých vzt'ahov.

3. Potreba autonómie vychádza zo záujmov a integrovaných hodnôt človeka. Táto potreba býva vysvetlovaná ako prirodzená potreba byt' dôležitý. Často sa zamieňa s vnímaním vlastnej nezávislosti. Pocit nezávislosti prestavuje nespoliehanie sa na externé zdroje. Autonómia vychádza skôr z jedincovho vnímania možnosti stanovit' alebo prijat' hodnoty, či normy, ktoré sa mu ponúkajú alebo sa od neho požadujú druhými za predpokladu, že s nimi kongruentne súhlasí, čiže u človeka je medzi prežívaním a postojmi k tejto realite je zhoda.

Dôležitým výstupom, rozhodujúcim pri tvorbe konštrukcii dotazníkov ako diagnostických nástrojov bolo formulovanie Seba-determinačného kontinua (obrázok 1) v rámci subteórie organizmickej integrácie.

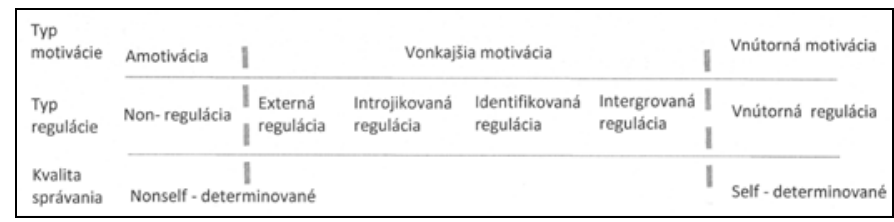

Obr. č. 1: Seba-determinačné kontinuum (viz Kuruc, 2017)

Ako vidíme na obr. 1 Ryan a Deci (2004) rozdel’ujú vonkajšiu motiváciu podl’a miery internalizácie do štyroch regulačných štýlov. S podobným rozdelením sa môžeme stretnút' u d'alší autorov ako Desoete, Royers a Buysse (2001).

Externá regulácia - predstavuje najmenej autonómnu formu vonkajšej motivácie. Obsahuje motívy ako je snaha vyhnút' sa trestu alebo získat' odmenu. Externá regulácia je všeobecne viditel'ná vtedy, ked' dôvodom pre vykonávanie správania je uspokojenie vonkajšej požiadavky. Externá regulácia má vonkajší lokus kauzality.

Introjikovaná regulácia (regulácia pasívne prevzatá) predstavuje ešte skôr vonkajšiu reguláciu, ktorá už je internalizovaná, ale nie príliš hlboko. Táto regulácia ešte nie je prijatá ako niečo skutočne človeku vlastné. Predstavuje formu internalizovanej regulácie, ktorá je teoreticky definovaná ako skôr kontrolujúca. Jedinec chce posilnit' svoje ego (chce vyniknút') alebo sa vyhnút' problémom (chce sa niekomu zapáčit'). Správanie je regulované na základe snahy vyhnút' sa pocitu viny a hanby, alebo dosiahnut' pocit sebahodnoty na základe pochvaly, ocenenia. Inak povedané, tento typ regulácie je založený na podmienenej sebaúcte (Deci a Ryan, 1995).

Regulácia cez identifikáciu - jedinec sa stotožňuje s reguláciou, vedome prisudzuje ciel'u osobnú hodnotu a vyhodnocuje ju ako osobne prospešnú (učí sa, aby získal odbornost' pre svoje budúce povolanie). Je už viac sebaurčujúcou formou vonkajšej motivácie. Zahŕn̆a vedomé oceňovanie ciel'ov správania, alebo regulácie a prijatie 
(akceptáciu) správania ako osobne dôležitého. Identifikácia predstavuje dôležitý aspekt procesu transformácie vonkajšej regulácie do skutočnej sebaregulácie. To, že sa jedinec identifikuje s aktivitou alebo hodnotou na vedomej úrovni, vyjadruje tým, že ju osobne schvaluje. Táto aktivita je potom sprevádzaná vysokým stupňom vnímanej autonómie.

Integrovaná regulácia - poskytuje základ pre najviac autonómnu formu motivácie správania. Tu dochádza k zhode vonkajších a vnútorných ciel’ov. K zhode dochádza vtedy, ked' identifikované hodnoty, či regulácie boli človekom ohodnotené a prijaté $\mathrm{v}$ zhode $\mathrm{s}$ jeho osobne podporovanými reguláciami, hodnotami, ciel'mi a potrebami. Integrovaná motivácia zdiel’a mnoho kvalít z vnútornej motivácie. Správanie korigované integrovanými formami regulácie je vykonané skôr za účelom dosiahnutia osobne dôležitých výsledkov, než pre inherentný záujem a potešenie, ktoré sú charakteristické pre vnútornú motiváciu. Činnost' jedinec vykonáva $\mathrm{z}$ vlastného popudu, pre osobné potešenie - učí sa, aby veciam porozumel, spoznal nové veci.

Teória sebaurčenia predstavuje eklektický model motivácie. Vychádza z predpokladu, že človek má prirodzenú tendenciu k vnútornej integrácii. Táto teória sa pokúša odpovedat' na to, akým spôsobom sú l’udia motivovaní v rôznych sociálnych kontextoch a ako v nich regulujú svoje správanie a prežívanie. Táto teória je vybudovaná na pilieroch tzv. organizmickej metateórie, ktorá vychádza z predpokladu, že zdrojom vývojových zmien je kombinácia vnútorných biologických zmien a síl, ktoré pochádzajú z prostredia (Ryan a Deci, 2004).

\section{Validita a reliabilita dotazníku SRQ-Academic}

V rámci teórie sebaurčenia bola vypracovaná sústava dotazníkov pre rozličné oblasti l'udskej činnosti. Dotazníky posudzujú individuálne odlišnosti v typoch motivácie a regulácie pre určitú oblast' - pole pôsobnosti. Otázky sa teda zameriavajú na konkrétne správanie (napr. pravidelné cvičenie).

O regulačných štýloch sa respondenti vyjadrujú do určitej miery nepresne. Pravdepodobne je to spôsobené tým, že ich nie je možné považovat' ani za osobnostnú črtu, ani za psychický stav. Regulačný štýl možno vnímat' niekde medzi osobnostnou črtov a psychickým stavom. (Ryan a Deci, 2000)

Samotný formát dotazníka zaviedli autori Ryan a Connell (1989). Každý z vytvorených dotazníkov sa dopytuje na príčinu používania respondentom voleného správania sa (alebo skupinu konaní) a potom poskytuje niekol'ko možných príčin podl’a predvolených štýlov regulácie a motivácie. Dotazníky, ktoré už boli overené sa zameriavaju na meranie regulácie a motivácie v určitom konkrétnom sociálnom kontexte.

Jedným z prvých dotazníkov, ktoré boli vytvorené a overené bol dotazník SRQAcademic (Self-regulation Questionnaire - Academic). Bol vytvorený pre cielovú skupinu žiakov nižšieho a vy̌šieho sekundárneho vzdelávania. Sústred’uje sa na aktivity spojené so školským prostredím.

Ako nástroj na zist'ovanie sebaregulačného štýlu učenia sa študentov sme použili dotazník SRQ-Academic (Ryan a Connell, 1989), ktorý bol štandardizovaný v roku 2017 na slovenskú kultúru (Kuruc, 2017). Dotazník meria charakter motivácie a sebaregulácie žiakov vo vztahu $\mathrm{k}$ učeniu sa $\mathrm{v}$ prostredí školy. Pre naše potreby sme dotazník modifikovali tak, aby zaznamenával charakter motivácie vo vzt’ahu k trom predmetom: matematika, prírodoveda a technika. V dotazníku boli tri hlavné otázky. Na každú otázku sa viazalo 8 odpovedí, ktoré boli škálované štvorstupňovou škálou. Charakter týchto 
odpovedí určoval, ktorý regulačný štýl daná odpoved’ sýti. Odpovede boli rovnomerne rozdelené medzi štyri hlavne regulačné štýly: externú reguláciu, introjikovanú reguláciu, identifikovanú reguláciu a vnútornú motiváciu. Vnútorná motivácia bola zahrnutá do tohto dotazníka vzhl'adom na to, že v rámci Teórie sebaurčenia sa vychádza z presvedčenia, že proces učenia sa je pre človeka prirodzenou potrebou. Ako výstupné skóre sa používa RAI - Relatívny autonómny index. Podl'a tohto indexu sa určuje celková orientácia motivácie a regulácie respondenta (viac Ryan a Deci, 2004 alebo Kuruc, 2017.

Reliabilitu dotazníka sme overovali troma spôsobmi. Prvý sme realizovali prostrednictvom výpočtu Split-half reliability, ktorá dosiahla hodnotu 0,687. Táto hodnota predstavuje akceptovatel'nú reliabilitu. Ako druhú metódu sme zvolili overenie reliability prostredníctvom Cronbachovej alfy, ktorá dosiahla hodnotu 0,845. Táto hodnota predstavuje taktiež uspokojivú reliabilitu. Tento koeficient je typický pri dotazníkoch, v ktorých sú položky škálované (všetky položky v dotazníku majú škály rovnakej hodnoty a dížky). Používa sa na posúdenie vnútornej konzistencie škál položiek dotazníka. Ako tretiu metódu na overenie reliability sme realizovali prostredníctvom Scott's homogenity, ktorá dosiahla hodnotu 0,647. Táto hodnota je taktiež akceptovatel'ná.

Na základe týchto zrealizovaných procesov sme mohli konštatovat', že nami zvolený výskumný nástroj spol’ahlivo a presne umožňuje vyhodnotit' aký sebaregulačný štýl prevláda u respondentov (nami oslovených študentov).

\section{Interpretácie výsledkov výskumu}

Výskumnú vzorku tvorilo 1090 respondentov. Z pohl'adu vol'by univerzít išlo o dostupný výber - všetky tri univerzity participujú na výskumnom projekte VEGA. Z pohl'adu zberu dát išlo o náhodný výber. Študenti boli plošne oslovení a dotazník bol administrovaný on-line.

Išlo o študentov bakalárskeho a magisterského stupňa štúdia na Pedagogických fakultách Univerzity Komenského v Bratislave (41 \%), Univerzity Mateja Bela v Banskej Bystrici (22 \%) a Katolíckej Univerzity v Ružomberku (37 \%). Medzi respondentmi boli študenti denného (65 \%), aj externého (35 \%) štúdia. Veková štruktúra respondentov bola nasledovná: vo veku 18 a 19 rokov bolo 8\% respondentov; vo veku 20 a 21 rokov bolo $35 \%$ respondentov; vo veku 22 a 23 rokov bolo $26 \%$ respondentov a vo veku 24 a viac bolo $31 \%$ respondentov. Prírodovedné predmety malo absolvovaných v čase vyplnenia dotazníka 61 \% študentov. Predmety s technickým zameraním už absolvovalo 52 \% a najviac tvorila skupina študentov, ktorí mali absolvované matematické predmety $91 \%$. Skupina študentov, ktorí v čase vypíňania mali absolvované všetky tri predmety tvorilo $45 \%$ respondentov. Z pohladu pohlavia dominovali vo výskumnej vzorke ženy a počet mužov bol zanedbatel'ný.

$\mathrm{V}$ nasledujúcej časti sa budeme venovat' zisteniam sebaregulácie a motivácie študentov vo vzt'ahu $\mathrm{k}$ technike.

\section{Technicky zamerané predmety}

Východiskovú vzorku tvorilo 52\% (n=570) respondentov zo základnej vzorky, ktorí už absolvovali počas doterajšieho štúdia predmety z technickým zameraním. Ide o najmenej zastúpenú skupinu z pomedzi nami skúmaných predmetov. Taktiež takto 
zamerané predmety sa objavujú až v neskorších ročníkoch štúdia. Ako nám ukazuje vel'kost' vzorky s technickými disciplínami sa študenti stretávajú výraznejšie menej ako s matematikou alebo prírodovedou.

Napriek tejto skutočnosti môžeme na obrázku nižšie vidiet' zaujímavý výsledok $\mathrm{v}$ rozložení frekvencie výskytu jednotlivých regulačných štýlov.

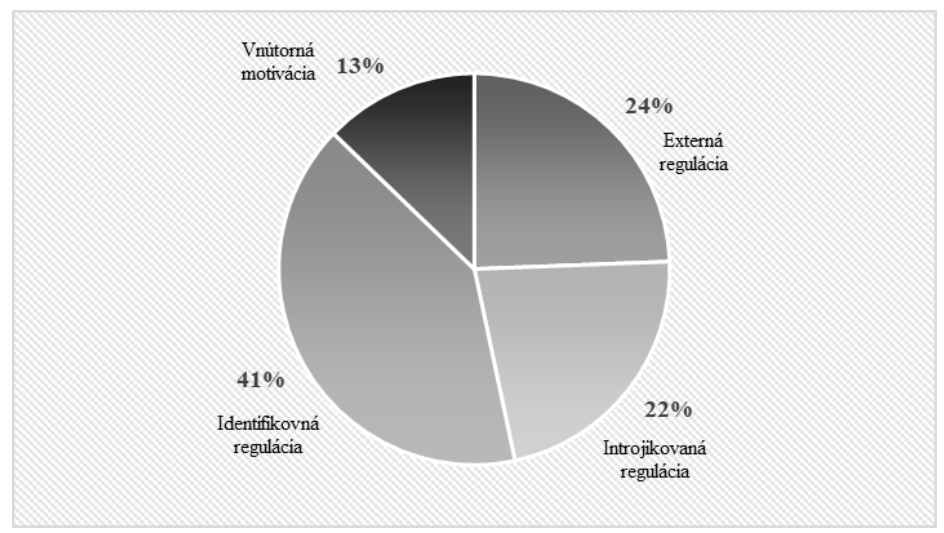

Obr. č. 2: Graf frekvencie výskytu regulačných štýlov v Technike

Vel’mi zaujímavé je výrazné zastúpenie relatívne autonómneho regulačného štýlu identifikovanej regulácie (Obr. č. 2 označená ako IDR) $41 \%$. Znamená to, že sa o tento predmet zaujímajú hlavne preto, že ho považujú za osobne dôležitý. Taktiež sa v tejto oblasti cítia kompetentní. Súčasne však treba povedat', že práve pri technike je najnižší výskyt IM štýlu - intrinsická (vnútorná) motivácia 13 \%. Ďalšie testovanie signifikantnosti týchto rozdielov ukázalo, že kým medzi výskytom intrinsickej motivácie pri technike a matematike je tento rozdiel štatisticky nevýznamný, tak medzi technikou a prírodovedou je rozdiel signifikantný. Znamená to, že výskyt intrinsickej motivácie, je štatisticky významný (na hladine citlivosti $\alpha=0,001$ ) nižší v skupine technických disciplín ako v skupine matematiky. Signifikantnost' sme testovali prostredníctvom Študentovho T-testu. Kontrolné regulačné štýly boli pomerne rovnomerne rozdelené.

Napriek tomu, že tento rozdiel sa po d'alšom testovaní signifikantnosti ukázal ako štatisticky nevýznamný, vnímame vyšší výskyt autonómne motivovaných regulačných štýlov ako pozitívne zistenie.

\section{Celkové vyhodnotenie absolvovaných predmetov}

Ako poslednú sme zo základnej vzorky vybrali tú skupinu respondentov, ktorí už počas svojho štúdia mali skúsenost' so všetkými nami skúmanými predmetmi. Túto skupinu tvorilo $45 \%(n=488)$ respondentov. Na grafe 7 môžeme vidiet' porovnanie frekvencie výskytu regulačných štýlov naprieč skúmaných disciplín.

Najvýraznejšie zastúpenie externej regulácie (d’alej ER) je pri predmete matematika 41 \%. Najnižšie zastúpená je ER pri technických disciplínach (19\%). Introjikovaná 
regulácia (IJR) je zastúpená približne rovnomerne pri všetkých troch disciplínach. Výskyt IJR vo vzorke bol celkovo najnižší.

Identifikovaná regulácia (IDR) je zastúpená vo vzorke výrazne. Najčastejšie je zastúpená v technike (31,6 \%), potom pri prírodovede (25,2 \%) a v matematike je zastúpený najnižšie (22,7 \%). Zhoduje sa to s vysokým výskytom ER pri matematických disciplínach.

Intrinsická motivácia (IM) - prototyp autonómneho regulačného štýlu je najvýraznejšie zastúpená pri technike (35 \%) a hned’ za ňou je prírodoveda (32 \%). S výrazným odstupom je IM zastúpená výrazne nižšie pri matematike (20,3 \%).

Signifikancia rozloženia frekvencie jednotlivých štýlov v predmetoch bola overovaná pomocou Chí-kvadrátu. Vo všetkých troch predmetoch išlo o signifikantné rozloženie na hladine citlivosti $\alpha=0,001$. Autonómne regulačné štýly sú najčastejšie zastúpené pri technike (67\%), potom nasleduje prírodoveda (57 \%) a ako posledná je matematika (43\%). Rozloženie kontrolných štýlov potvrdzuje vyššie zastúpenie autonómnych regulačných štýlov. Najčastejšie sa kontrolné štýly objavujú pri matematických disciplínach (57 \%), potom v prírodovede (43 \%) a najnižšie bol zastúpený pri technike (33\%).

Tieto zaujímavé rozdiely sme testovali prostredníctvom testu dobrej zhody Chí-kvadrátu. Všetky rozdiely sa ukázali ako štatisticky významné na hladine významnosti $\alpha=0,001$. Aj z tohto dôvodu môžeme výsledky považovat' za štatisticky významné a teda relevantné.

\section{Záver}

Výsledky výskumu preukázali, že najvýraznejšie zastúpenie externej regulácie (ER) je pri matematických disciplínach $41 \%$. Najnižšie zastúpená je ER pri technických disciplínach (19\%). Myslíme si, že to otvára priestor pre diskusiu o možnosti užšieho prepojenia matematiky sprírodovednými predmetmi a technickým vzdelávaním. Matematika je dlhodobo neoblúbeným predmetom u študentov učitel'stva pre primárny stupeň. Naše výsledky sú toho dôkazom. Východisko vidíme vo väčšom priblížení až prekrývaní týchto troch vzdelávacích oblastí.

Introjikovaná regulácia (IJR) je zastúpená približne rovnomerne pri všetkých troch disciplínach. Výskyt IJR vo vzorke bol celkovo najnižší, čo poukazuje na to, že motivácia sýtená z obáv s prežívania pocitov viny a hanby alebo z podmienenej sebaúcty nie je vel'mi rozšírená. Zároveň však treba povedat', že hoci je IJR regulačným štýlom sýteným hlavne z kontrolnej motivácie, predstavuje viac integrované motívy do osobnosti človeka ako sú tie, ktoré sú ukotvené v externej regulácii.

Ak sa vrátime na začiatok ku kontinuu sebaurčenia môžeme vidiet', že to čo je pred externou reguláciou môžeme označit' ako amotiváciu. Čiže stav, v ktorom človek vo svojom vnútri nenachádza žiadne motívy ku konaniu, jeho správanie a prežívanie je neregulované. A kvalita jeho správania je definovaná ako nonself-determinovaná (je určovaná mimo jadro osobnosti človeka, ktoré sa označuje ako ego - self). U l'udí s takýmto nastavením regulácie a motivácie, môžeme len vel'mi t’ažko predikovat' ich konanie.

Vo vzorke je výrazne zastúpená identifikovaná regulácia (IDR). Ide o autonómny regulačný štýl. Najčastejšie je zastúpený v technických disciplínach (31,6 \%) potom v prírodovede $(25,2 \%)$ a najnižšie je zastúpený v matematike (22,7 \%). Intrinsická motivácia (IM) - výrazne autonómny regulačný štýl, prototyp vnútornej motivácie, je 
najvýraznejšie zastúpený pri technických disciplínach (35 \%) ablízko nich je prírodoveda (32 \%). S výrazným odstupom IM je matematika (20,3 \%).

V súvislosti s technickým vzdelávaním výsledky výskumu poukázali na dve skutočnosti: predmety technického charakteru sú najslabšie zastúpené vo vzdelávacom programe primárneho stupňa. $\mathrm{V}$ porovnaní s matematikou, ktorá mala $100 \%$ zastúpenie a prírodoveda (66,13 \%) technické disciplíny majú len 57,11 \% -né zastúpenie.

Vzhl'adom na to, že technika je v programoch pre primárny stupeň ponúkaná ako výberový predmet, najviac sa tu prejavil autonómny regulačný štýl: technika (31,6 \%), prírodoveda (25,2 \%) a matematika (22,7 \%). Je na zváženie, či je správne ponechat' technické vzdelávanie na dobrovol'nej báze vo vysokoškolskej príprave, ked' pracovné vyučovanie je súčast'ou štátneho kurikula a je to povinný predmet v bežnej praxi na školách. Taktiež sa otvára priestor pre väčšie prepojenie týchto troch predmetov v samotných programoch pripravujúcich budúcich učitel'ov na primárnom stupni vzdelávania.

Spracované v rámci projektu VEGA 10443/18 Analýza sebaregulačných štýlov učenia sa študentov odboru predškolská a elementárna pedagogika.

\section{Literatúra}

Blatný, M., Kohoutek, T., Janušová, P. (2002). Situačně kognitivní a osobnostní determinanty chování v zátěžové situaci. Československá psychologie, 46, 2, 97-108.

Boekaerts, M. (2005). Motivace k učení. In Walberg, H. J. (ed). Efektivní učení ve škole. Praha: Portál, s. 55-76.

Boekaerts, M. (2005). Self-regulation: With a focus on the self-regulation of motivation and effort. In W. Damon, R. Lerner (Series Eds.), I.E. Sigel, K.A. Renninger (Vol. Eds.), Handbook of child psychology, Vol. 4, Child psychology in practice (6th edn.). New York: Wiley.

Braisby, N., Gellatly, A. (Eds.) (2005). Cognitive psychology. Oxford: Oxford University Press.

Corno, L. (2008). Work Habits and Self-Regulated Learning: Helping Students to Find a „Will“ from a „Way“. In Zimmerman, B. J., Schunk, D. H. (Eds.) Motivation and SelfRegulated Learning: Theory, Research, and Applications. New York, London: Routledge, 2008, p. 197-222.

Částková, P. a Stolinská, D. (2014). Sebereflexe žáka v technické výchově na primární škole. In. Trendy ve vzdělávání. Havelka, M., Chráska, M., Klement, M. a Serafín, Č. s. 31-35. Dostupné z: http://www.kteiv.upol.cz/tvv_web/tvv14/ tvv_2014_proceedings.pdf Deci, E. L., Ryan, R. M. (1975). Intrinsic motivation. New York: Plenum Publishing Co. Deci, E. L., Ryan, R. M. (1980). The psychology of self-determination. Lexington, MA: D.C. Heath (Lexington Books)

Deci, E. L., Ryan, R. M. (1995). Human autonomy: The basic for true self-esteem. In M. Kernis Ed.), Efficacy, agency, and self-esteem (pp. 31-49). New York: Plenum.

Deci, E. L., Ryan, R. M (Eds.) (2004). Handbook of self-determination research. Rochester, NY: The University of Rochester Press.

Desoete, A., Roeyers, H., Buysse, A. (2001). Metacognition and mathematical problem solving in grade 3. Journal of Learning Disabilities, 34, 435-449.

Garcia, T. (1995). The Role of Motivational Strategies in Self-Regulated Learning. In Pintrich, P. R. (Ed.) Understanding Self-Regulated Learning. San Francisco: Jossey-Bass Publishers, p. 29-42. 
Hrbáčková, K. (2010). Kognitivní a nonkognitivní komponenty procesu autoregulace učení žákủ. Disertační práce. Brno: MU.

Hrbáčková, K. (2011). Rozvoj autoregulace učeni studentů. Praha: Hnutí R.

Klement, M., Dostál, J., \& Bártek, K. (2017). Výhody a výzvy využití ICT nastroju ve vzdělávání. In Journal of Technology \& Information Education, 10 (1), s. 158-160.

Křivohlavý, J. (2003). Psychologie zdraví. 2. vyd. Praha: Portál.

Kuruc, M. (2017). Akademická a prosociálna motivácia v škole. Bratislava: Univerzita Komenského.

Hrabal, V., Man, F., Pavelková, I. (1989). Psychologické otázky motivace ve škole. Praha: SPN.

Kusák, P., Dařílek, P. (2002). Pedagogická psychologie. Olomouc: Univerzita Palackého.

Maňak, J. (2006). Determinanty kurikula. In Maňak, J.; Janík, T. (ed.). Problémy kurikula základní školy. Brno: MU, s. 23-28.

Maňák, J. (2009). Vzdělávání ve společnosti vědění. In Janík, T., Švec, V. a kol. K perspektivám školního vzdělávání. Brno: Paido, s. 11-20.

Mareš, J. (2013). Pedagogická psychologie. Praha: Portál.

Nakonečný, M. (1996). Motivace lidského chování. Praha: Academia.

Národný program výchovy a vzdelávania v SR na najbližších 15-20 rokov. Milénium. (1998).

Nolen-Hoeksema, S. a kol. (2012). Psychologie Atkinsonové a Hilgarda. Praha: Portál.

Klement, M., Chráska, M., Dostál, J. \& Marešová, H. (2012). E-learning: elektronické studijní opory a jejich hodnocení. Olomouc-EU: Agentura Gevak.

Pintrich, P. R. et al. (1991). A Manual for the Use of the Motivated Strategies for Learning Questionnaire (MSLQ). Ann Arbor: National Center for Research to Improve Postsecondary Teaching and Learning.

Prensky, M. (2001). Digital Natives, Digital Immigrants. Dostupné na: http://www.marcprensky.com/writing/Prensky\%20\%20Digital\%20Natives,\%20Digital\% 20Immigrants\%20-\%20Pa

Ryan, R. M., \& Connell, J. P. (1989). Perceived locus of causality and internalization: Examining reasons for acting in two domains. Journal of Personality and Social Psychology, 57, 749-761.

Ryan, R. M., Deci, E.L. (2000). Self-determination Theory and the facilitation of intrinsic motivation, social development, and well-being. In: American Psychologist, 55, pp. 68-78.

Ryan, R.M. (2012). Motivation and the Organization of Human Behavior: Tree Reasons for Reemergence of a Field. In: Ryan, R.M. (Ed.), The Oxford Handbook of Human Motivation. New York: The Oxford University Press, pp 3-10.

Sillamy, N. (2001). Psychologický slovník. Olomouc: Univerzita Palackého v Olomouci. UNESCO (1997). Učení je skryté bohatství. „Vzdělávání pro 21. století“. Praha: Ústav pro informace ve vzdělávání.

Wolters, C. A., Rosenthal, H. (2000). The relation between students'motivational beliefs and thein use of motivational regulation strategies. International Journal of Educational Research, 33(7-8), p. 801-820.

Zimmerman, B. J. (2002). Becoming a self-regulated learner: an overview. Theory into practice. 41(2), p. 64-70. 